\title{
Thermal Inactivation Study of Partially Purified PPO from Algerian Dates (Phoenix dactylifera L cv Tedala ) Using Pyrogallol as Substrate
}

\author{
Benaceur Farouk, Gouzi Hicham and Meddah Boumedienne
}

\begin{abstract}
This study investigated the stability and thermal inactivation of Tedala PPO using pyrogallol as substrate in range of temperature between 60 and $75^{\circ} \mathrm{C}$. The kinetic of Tedala PPO inactivation by temperature followed a biphasic model .The D values during thermal inactivation varied from 1771,21 to $1,7 \mathrm{~min}$ for Tedala PPO and the corresponding $\mathrm{Z}$ values and activation energy (Ea) were $6,6^{\circ} \mathrm{C}$ and $334,3 \mathrm{~kJ} / \mathrm{mol}$ and $4,8^{\circ} \mathrm{C}$ and $458,7 \mathrm{~kJ} / \mathrm{mol}$ for both heat sensitive and heat stable fractions, respectively. Likewise To understand therefore the behavior of enzyme with increase of temperature,the thermodynamic study was carried out and their parameters $(\Delta \mathrm{H}, \Delta \mathrm{G}$ and $\Delta \mathrm{S})$ were calculated.
\end{abstract}

Keywords - Tedala, Triphenol activity, Pyrogallol, Thermal inactivation, Thermodynamic analysis.

\section{INTRODUCTION}

The date is the fruit of date palm, a sweet fruit with a composition rich in several nutrititious elements including proteins, simple sugars, vitamins, and secondary metabolites [1].The PPO is a particular enzyme found in fruits and vegetables such as dates involved inter alia in the phenomenon of enzymatic browning via its oxidation of phenolic compounds. Its control seems to be a necessity to control the damage related to the loss of organoleptic properties. [2].In the last decade, several research paper have been focused on browning control using different methods are by heating $[3,4,5]$ physical methods such as ultrasound [4,5]. and high pressure [6].

Heat treatment is very effective method for enzyme inactivation. The choice of time period exposition is very delicate to control the enzyme activity..According to values of optimal temperature of PPO from different sources ,this enzyme is considered as thermostable enzyme [7].To our knowledge, no behavior of thermal inactivation of oxidation of pyrogallol by Tedala PPO. Consequently, the objective

Benaceur Farouk/Laboratoire d'enzymologie, ,Département de biologie Faculté des Sciences, Université Amar Telidji, Laghouat 03000, Algeria.

Gouzi Hicham/ Laboratoire de Chimie Organique, Substances Naturelles et Analyse (COSNA), Département de Chimie, Faculté des Sciences, Université Abou Bekr Belkaid, Tlemcen 13000, Algeria.

Meddah Boumedienne/Laboratoire de Bioconversion, Génie Microbiologique et Sécurité' Sanitaire, Faculté' des Sciences de la Nature et de la Vie, Université' de Mascara. Route Mamounia, 29000 Mascara, Algérie highlighted in this study sought to understand the behavior of the oxidation of a triphneolic substrate by polyphenol oxidase extracted from an original source. Variations in thermodynamic characters of pyrogallol oxidation were studied to evaluate its application in control of enzymatic browning during storage of Tedala fruit Date.

\section{MATERIALS AND METHODS}

\section{A. Materials}

The plant material used in the study consists of Tedala date. The dates were purchased from the local market of Laghouat at full maturity(Tamar stage) and and kept at $-20 \circ \mathrm{C}$ for three months before use. The identification was made by a botanical specialist. Pyrogallol and polyvinyl(poly)pyrrolidone (PVPP) were purchased from Sigma Aldrich.All other chemicals and reagents were of analytical grade.

\section{B. Methods}

\subsection{Partial Purification And Activity Assay}

To prepare the crude enzyme extract, Frozen dates (Tedala) dates were cut into thin slices weighed (500g) and homogenized in a blender with $1000 \mathrm{~L}$ of cold phosphate buffer at $\mathrm{pH}$ 7.0-0.05 $\mathrm{M}$ and $4 \%$ Polyvinyl(poly) pyrrolidone (PVPP) for $2 \mathrm{~min}$. After filtration of the homogenate through 4 layers of cheesecloth and centrifuged, the resultant filtrate was centrifuged at $10,000 \mathrm{~g}$ for $20 \mathrm{~min}$ at $4^{\circ} \mathrm{C}$, and the supernatant was collected.The resultant filtrate was centrifuged at $10,000 \mathrm{~g}$ for $20 \mathrm{~min}$ at $10^{\circ} \mathrm{C}$, and the up fraction was collected. The supernatant was brought to $90 \%$ (NH4)2SO4 saturation with solid (NH4)2SO4. The supernatant was discarded and the precipitate was dissolved in a small amount of $0.05 \mathrm{M}$ sodium phosphate buffer, $\mathrm{pH}$ 7.0. The concentrated enzyme solution was dialyzed at $4^{\circ} \mathrm{C}$ against $0.05 \mathrm{M}$ sodium phosphate buffer, $\mathrm{pH}$ 7.0, with two changes of the buffer during dialysis to remove the residual ammonium sulfate.Then A last concentration of dialysis bags using PEG was carried out and a total volume of $50 \mathrm{ml}$ constituted the PPO partially purified was kept frozen at $-150 \mathrm{C}$ until use for further experiences.

PPO activity was determined by measuring the initial rate of o-benzoquinone formation, as indicated by an increase in 
absorbance at $400 \mathrm{~nm}$ using pyrogallol as substrate [8]. A Shimadzu UV spectrophotometer (UV 1800) was used for analysis .One unit of enzyme activity was defined as the amount of enzyme that caused an increase in absorbance of $0.001 / \mathrm{min}$ for $1 \mathrm{~mL}$ enzyme . All activity analyses performed in this work were carried out in triplicate and the averages of data were considered. The error bars represent standard deviation (SD).

\subsection{Effect Of $\mathrm{pH}$ And Temperature}

The residual enzymatic activity expressed as relative to the maximal activity was monitored as a function of $\mathrm{pH}$ change and temperature using pyrogallol as susbtrat at saturating concentration $(100 \mathrm{mM})$. Two buffer systems were used: $\mathrm{pH}$ ( 2.5-6) with acetate buffer and $\mathrm{pH}(6.5-8)$ with phosphate buffer while the thermal stability study was achieved in the temperature range $30-90$ (in $10^{\circ} \mathrm{C}$ increments) with incubation time of $10 \mathrm{~min}$ in water bath. After heat treatment, the tubes are cooled rapidly in cold water and the residual enzymatic activity is measured at three $\mathrm{pH}$ values $(3 ; 5$ and 7) while also varying the time.

\subsection{Heat inactivation kinetics}

The thermal inactivation of partially purified Tedala PPO was studied at range of temperature between $60-75^{\circ} \mathrm{C}$ and at atmospheric pressure. At predetermined time intervals, $100 \mu \mathrm{l}$ aliquots were pipetted from a tube preheated in a bath in Eppendorf tubes which were immediately immersed in an ice bath to instantly stop thermal inactivation.

Measurement of the residual enzymatic activity was performed against a blank containing the untreated enzyme. To initiate the rection, $50 \mu \mathrm{l}$ of the enzyme solution previously heated with $0.5 \mathrm{ml}$ of $100 \mathrm{mM}$ pyrogallol was used. The residual activity allows the estimation of activity loss rates by calculating the ratio between the activity before and after treatment.

A first order biphasic model was used to describe the inactivation process (Eq. 1) [9]. Such model had been observed for the thermal inactivation of PPOs from several sources $[9,10,11,12]$.

$$
\mathrm{A}=A_{S} \exp \left(-k_{S} t\right)+A_{L} \exp \left(-k_{L} t\right)
$$

where the activities and inactivation rate constants of the stable(s) and the labile(L) fractions are respectively, AS; AL and $\mathrm{kS} ; \mathrm{kL}$.

The inactivation rate constants of the heat labile and stable fraction were estimated using Arrhenius model (Eqs. 2, 3) :

$$
\begin{aligned}
& \ln \left(k_{L}\right)=\ln \left(k_{0}\right)+\left[\frac{-E_{a L}}{R}\left(\frac{1}{T_{0}}-\frac{1}{T}\right)\right] \\
& \ln \left(k_{S}\right)=\ln \left(k_{0}\right)+\left[\frac{-E_{a R}}{R}\left(\frac{1}{T_{0}}-\frac{1}{T}\right)\right]
\end{aligned}
$$

where $\mathrm{T}$ and $\mathrm{T}_{0}$ are the experimental and reference temperatures $\left({ }^{\circ} \mathrm{K}\right), \mathrm{Ea}_{\mathrm{L}}$ and $\mathrm{Ea}_{\mathrm{R}}$ are the activation energy values of the heat labile and stable fractions $(\mathrm{kJ} / \mathrm{mol}), \mathrm{R}$ is the universal gas constant $(8.314 \mathrm{~J} / \mathrm{mol} . \mathrm{K})$ and $\mathrm{k}$ and $\mathrm{k}_{0}$ are the inactivation rate constants $\left(\mathrm{s}^{-1}\right)$ at $\mathrm{T}$ and $\mathrm{T}_{0}$ respectively

Half-life $\left(\mathrm{t}_{1 / 2}\right)$ value of inactivation is given by the expression (Eq. 4):

$$
t_{1 / 2}=\frac{\ln (2)}{k}
$$

D-value is the time (min) needed to reduce the initial activity $90 \%$. It was related to k-values by equation (5) and mathematically expressed by:

$$
D=\frac{\ln (10)}{k}
$$

The value of $\mathrm{Z}_{\mathrm{T}}$ (temperature sensitivity parameter) is calculated from the curve of decimal logarithm of reduction time $(\log \mathrm{D})$ as a function of the temperature $\left(\mathrm{T}\right.$ in $\left.{ }^{\circ} \mathrm{C}\right)$ [7].Thus, to understand further thermal denaturation, thermodynamic parameters (Gibbs free energy change $(\Delta \mathrm{G})$, the enthalpy change $(\Delta H)$ and entropy change $(\Delta S)$, were estimated using following equations $(6,7,8)$ :

$$
\begin{gathered}
\Delta G=-R \cdot T \cdot \ln \left(\frac{k \cdot h_{p}}{K_{B} \cdot T}\right) \\
\Delta H=-E_{a}-R \cdot T \\
\Delta S=\left(\frac{\Delta H-\Delta G}{T}\right)
\end{gathered}
$$

where $\mathrm{K}_{\mathrm{B}}$ is the Boltzmann's constant $(1.3806 \times 10-23 \mathrm{~J} / \mathrm{K})$, $\mathrm{h}_{\mathrm{P}}$ is the Planck's constant $(6.6262 \times 10-34 \mathrm{~J} . \mathrm{s})$, and $\mathrm{k}$ is the inactivation rate constant of each temperature (s-1).

\subsection{Data Analysis}

For data analysis, curve fitting with linear and Nonlinear Regressions was performed using various software; Table Curve TM 2D v2.03 (Copyright 1989-1994. AISN Software) and SigmaPlot Version 12.0 (Copyright (C) 2011 Systat Software, Inc.). Analysis of variance (ANOVA) was carried out to evaluate significant $(\mathrm{P}<0.005)$ differences between samples.

\section{RESUlTS AND DISCUSSION}

\section{A. Effect Of PH}

The kinetic of the oxidation of pyrogallol by Tedala PPO as a function of the $\mathrm{pH}$ (Fig.1) showed only one peak of optimal activity at value $\mathrm{pH}=6$, either side of this $\mathrm{pH}$, there is a decrease in enzyme activity which can be explained by modification of interactions affinity between the active site of the enzyme and substrate via changes in the degree of ionization of pyrogallol and / or amino acid residues of the active site [7]. 


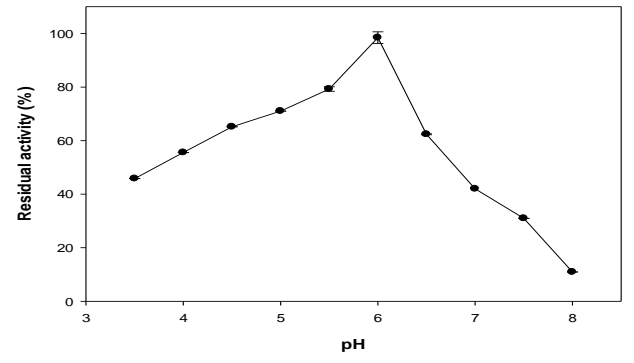

Fig 1. Residual activity of the Tedala PPO as a function of the $\mathrm{pH}$. (In the presence of pyrogallol as substrate). At $30^{\circ} \mathrm{C}$

Our results are similar to the value of $\mathrm{pH}$ found for the PPO of Ataulfo mango (Mangifera indica) [13] and different from the optimum $\mathrm{pH}$ of boorage PPO (Trachystemon orientalis L.) [14].

\section{B. Thermal Stability}

The temperature stability curve for the Tedala PPO using pyrogallol as substrate is shown in Fig. 2. Temperature optimum of Tedala PPO activity is $65^{\circ} \mathrm{C}$.

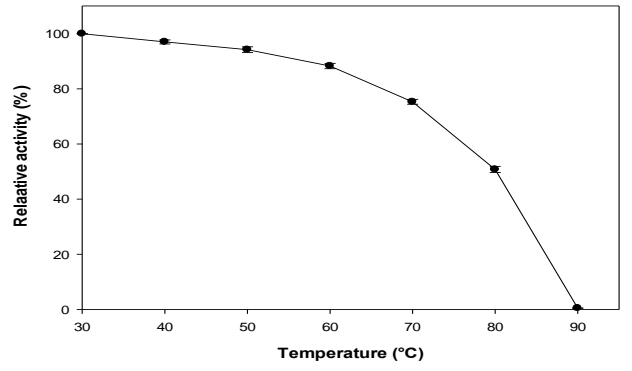

Fig 2. Thermal Tedala PPO as a function of the temperature increase at $\mathrm{pH} 6$.

At temperatures higher than $70^{\circ} \mathrm{C}$ the enzyme was increasingly less stable and completely inactivated at $90^{\circ} \mathrm{C}$. Likewise, the variation in the enzymatic activity of Tedala PPO as a function of the combined effect of $\mathrm{pH}$ and temperature was reported (Fig 3)

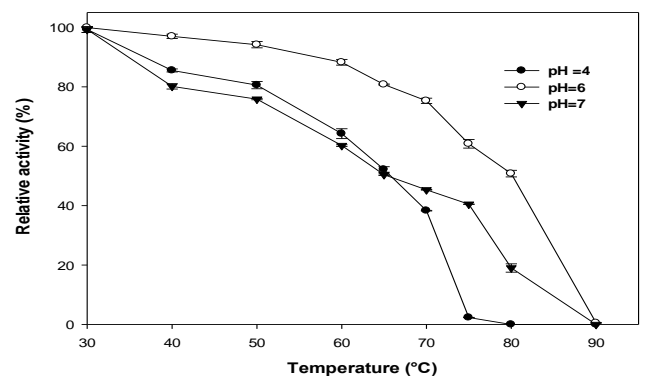

Fig 3. Thermal stability of the Tedala PPO after 10 min of heat treatment as function of $\mathrm{pH}$ using pyrogallol as substrate.

A sudden change in the values of these two physicochemical parameters will have a consequence on the enzymatic kinetics.The monitoring of the enzymatic activity at three ph values as a function of temperature increase provide a complementary idea about the kinetic behavior of the enzyme and its stability.
We noted that the thermal stability is affected with the ph change. Better stability is proportional to the optimum value of ph (ph 5) which implies that the enzymatic activity requires several favorable conditions to ensure good stability and therefore a better yield. On the light of these results we can considered the Tedala PPO as thermostable enzyme which is similar to the behavior of cherry (Malpighia gelabra L.). [15], and Wheat PPO (Triticum aestivum L.) [16].

\section{Heat Kinetic Inactivation}

\section{1 kinetic Analysis For Thermal Inactivation}

Based on the results of thermal stability, a detailed kinetic study of isothermal inactivation of Tedala PPO was performed in the range from 60 to $75^{\circ} \mathrm{C}$ at atmospheric pressure with different exposure times using pyrogallol as substrate..As expected, the extent of PPO denaturation increased with temperature and treatment time.Thus,a biphasic fractional inactivation kinetics was observed with sensitive heat and stable heat fractions. This biphasic first order model was reported for Garlic PPO [17] and white Yam PPO [18].The inactivation started at $70^{\circ} \mathrm{C}$, and after $5 \mathrm{~min}$ and $30 \mathrm{~min}$ of heat treatment, the enzyme retained approximately $68 \%$, and $37 \%$ of its initial activity, respectively. When the enzyme was exposed to $75^{\circ} \mathrm{C}$ for $5 \mathrm{~min}, 8 \mathrm{~min}$ and $12 \mathrm{~min}$, of heat treatment, the enzyme retained this time more than $63 \%, 52 \%$ and $41 \%$ of its initial activity, respectively.

The values of the thermal inactivation parameters of Tedala PPO are shown in Table 1,the half-life (t1/2) and the decimal reduction time (D-value) are important parameters commonly used in the characterization of enzyme stability. It can be observed that the t1/2 and D-values decreased with increase in temperatures for both the labile and the heat resistant fractions. In literature, many studies have reported thermal inactivation .[3, 5,19].

Table 1.

Comparing the $\mathrm{D}$ and $\mathrm{t} 1 / 2$ values of Tedala PPO with other sources at the same temperature $\left(70^{\circ} \mathrm{C}\right)$, Tedala fruit date PPO was more thermostable than PPO obtained from mushroom, $(\mathrm{t} 1 / 2=0.83 \mathrm{~min} ; \mathrm{D}=2.7 \mathrm{~min})$ [3] but less thermostable than PPO from Cape gooseberry $(\mathrm{t} 1 / 2=19 \mathrm{~min} ; \mathrm{D}=63.2 \mathrm{~min})$ (Bravo and Osorio,2016) and bayberry $(\mathrm{t} 1 / 2=19 \mathrm{~min} ; \mathrm{D}=$ $63.2 \mathrm{~min}$ ) [5]. The values of kinetic of heat activation of PPO from differences sources may differ in relation to their ability to adapt to climatic conditions. The values of activation energy (Ea) was calculated using the Arrhenius, a key parameter to quantify the influence of temperature on the inactivation rate constant .The activation energy of the heat-labile $\left(\mathrm{Ea}_{\mathrm{L}}\right)$ and heat-resistant fractions $\left(\mathrm{Ea}_{\mathrm{R}}\right)$ were $334,3 \mathrm{~kJ} / \mathrm{mol}$, and 458,7 $\mathrm{kJ} / \mathrm{mol}$ respectively. A high activation energy (Ea) values reflect a greater sensitivity of the enzyme to temperature change [20] which indicates that the stable fraction is more sensitive to temperature increase than the labile fraction. Similarly higher values of activation energy for the stable fraction were reported for PPOs from Yacon (Smallanthus sonchifolius) (16.05 compared to $72.08 \mathrm{~kJ} / \mathrm{mol})[12]$ and Strawberry (Fragaria ananassa, cv. Camarosa) (57 compared 
to $99 \mathrm{~kJ} / \mathrm{mol}$ ) [21].

TABLE I

\begin{tabular}{ccccc}
\hline $\begin{array}{c}\mathrm{T} \\
\left({ }^{\circ} \mathrm{C}\right)\end{array}$ & \multicolumn{2}{c}{ Heat-labile fraction } & \multicolumn{2}{c}{ Heat-resistant fraction } \\
\cline { 2 - 5 } & $\begin{array}{c}D_{L} \\
(\mathrm{~min})\end{array}$ & $\begin{array}{c}t_{1 / 2} \\
(\mathrm{~min})\end{array}$ & $\begin{array}{c}D_{S} \\
(\mathrm{~min})\end{array}$ & $\begin{array}{c}t_{1 / 2} \\
(\mathrm{~min})\end{array}$ \\
\hline 60 & $319,8 \pm 13$ & $96,2 \pm 0.5$ & $1771.21 \pm 2.15$ & $533.19 \pm 1.55$ \\
65 & $75,03 \pm 0.4$ & $22,5 \pm 0.3$ & $500.56 \pm 1.75$ & $150.68 \pm 1.34$ \\
70 & $12,3 \pm 0.2$ & $3,7 \pm 0.1$ & $190.29 \pm 1.05$ & $57.28 \pm 0.73$ \\
75 & $1,7 \pm 0.1$ & $0,5 \pm 0.0$ & $38.69 \pm 0.8$ & $11.64 \pm 0.51$ \\
\hline \multicolumn{3}{c}{$\mathrm{Zt}\left({ }^{\circ} \mathrm{C}\right)=6,6 \pm 0,5$} & $\mathrm{Zt}\left({ }^{\circ} \mathrm{C}\right)=4,8 \pm 0,2$ \\
\cline { 2 - 5 } & $\mathrm{E}_{\mathrm{aL}}(\mathrm{kJ} / \mathrm{mol})=334,3 \pm 2,5$ & $\mathrm{EaR}_{\mathrm{R}}(\mathrm{kJ} / \mathrm{mol})=458,7 \pm 3,1 \mathrm{~kJ} / \mathrm{mol}$
\end{tabular}

The $\mathrm{Z}_{\mathrm{T}}$ values of Tedala PPO were 6,6 and $4,8^{\circ} \mathrm{C}$ for heatstable and heat-resistant fractions, respectively, Various values of $\mathrm{Zt}$ were reported within large range: $9,41^{\circ}-10,4 \mathrm{C}$ for Victoria grape PPO [10], $13,6^{\circ} \mathrm{C}$ for bayberry PPO[5] $29.41^{\circ} \mathrm{C}$ for edible Yam PPO [22], and $104.2^{\circ} \mathrm{C}$ for pineapple pure PPO [23]. These variations in PPO inactivation kinetic parameters may be due to the method of extraction and degree of purification to the agronomic and climatic conditions of plants or fruits under which they were grown, and to the type of substrate used.

\subsection{Thermodynamic Analysis For Thermal Inactivation}

The thermodynamic study is very useful to understand the thermal denaturing effect on the enzymatic activity, it makes it possible to have an idea about the enzyme stability on range values of temperature at fixed time intervals using three important kinetic parameters: The Gibbs free energy of activation $(\Delta \mathrm{G})$, the number of broken covalent bonds or the enthalpy of the liaisons $(\Delta \mathrm{H})$, and thus the degree of disorder $(\Delta \mathrm{S})$. The tertiary structure is maintained thanks to the sum of several stabilizing and destabilizing forces released as thermal energy.[3].The Gibbs free energy of activation change is considered as the energy barrier for enzyme inactivation. $\Delta \mathrm{H}$, enthalpy change, a measure of the number of covalent bonds broken, and $\Delta \mathrm{S}$, the entropy change, which is a measure of net enzyme and dissolvent disorder, of the thermal inactivation of the Tedala dates PPO were calculated using pyrogallol as substrate in the temperature range of $60-75^{\circ} \mathrm{C}$ and are listed in Table 2.

The results shows that all thermodynamic parameters values changes with the increase of temperature. The $\Delta \mathrm{G}$ values for heat-sable and heat-labile fractions were ranged between 106,1 to $122,6 \mathrm{~kJ} \mathrm{~mol}-1$, in the same order of magnitude expected for protein and enzyme denaturation (100 kJ mol-1) [3].A significant reduction of $\Delta G$ values for the Tedala PPO was noticed indicating that destabilization of this protein followed the rise in temperature (Table 2).The $\Delta \mathrm{G}$ values obtained for Tedala PPO were quite similar to those obtained for PPOs from vanilla bean $(97.58 \mathrm{~kJ} / \mathrm{mol})$ [24], and mushromm (103 kJ/mol) [3].

For the enthalpy, the values $\Delta \mathrm{H}$ for heat-stable fraction were higher than those of heat-labile fraction.The higher values of $\Delta \mathrm{H}$ are proportional to the number of non-covalent bonds present in the enzyme molecule, which is going to be more stable [24].The $\Delta \mathrm{H}$ value found in this study was much higher than those reported for vanilla bean PPO for (89.24 $\mathrm{kJ} / \mathrm{mol})$ [25] and less than Victoria grape PPO $(250 \mathrm{~kJ} / \mathrm{mol})$ [10].

\begin{tabular}{|c|c|c|c|c|c|c|}
\hline \multirow{2}{*}{$\begin{array}{c}\mathrm{T} \\
\left({ }^{\circ} \mathrm{C}\right)\end{array}$} & \multicolumn{2}{|c|}{$\begin{array}{c}\Delta H \\
(\mathrm{~kJ} / \mathrm{mol})\end{array}$} & \multicolumn{2}{|c|}{$\begin{array}{c}\Delta G \\
(\mathrm{~kJ} / \mathrm{mol})\end{array}$} & \multicolumn{2}{|c|}{$\begin{array}{c}\Delta S \\
(\mathrm{~J} / \mathrm{mol} / \mathrm{K})\end{array}$} \\
\hline & $\Delta H_{L}$ & $\Delta H_{R}$ & $\Delta G_{L}$ & $\Delta G_{R}$ & $\Delta S_{L}$ & $\Delta S_{R}$ \\
\hline 60 & $204.4 \pm 3.0$ & $456.0 \pm 3.0$ & $114.6 \pm 0.8$ & $126,4 \pm 0.8$ & $269.6 \pm 5.0$ & $989,5 \pm 8.0$ \\
\hline 65 & $204.3 \pm 3.0$ & $455.9 \pm 7.0$ & $112,3 \pm 0.6$ & $120,4 \pm 0.9$ & $272,3 \pm 5.0$ & $992,5 \pm 7.0$ \\
\hline 70 & $204.3 \pm 2.0$ & $455.9 \pm 4.0$ & $108,8 \pm 0.7$ & $155,5 \pm 0.6$ & $278,2 \pm 6.0$ & $992,2 \pm 9.0$ \\
\hline 75 & $204.3 \pm 2.0$ & $455.8 \pm 5.0$ & $104,9 \pm 0.5$ & $111,6 \pm 0.7$ & $285,5 \pm 5.0$ & $989,1 \pm 8.0$ \\
\hline
\end{tabular}

All $\Delta \mathrm{S}$ values for thermal inactivation of Tedala date fruit PPO in the temperature range 60 to $75^{\circ} \mathrm{C}$ were positive indicate that there are a significant processes of aggregation with increase in disorder, or randomness, of the enzyme/solvent system upon denaturation which induced reduction of $\Delta \mathrm{G}$ value[3].In general, entropy activation has a dominant role in the thermal inactivation of proteins in aqueous solutions whose enzyme will alternate between a high enthalpic state and low entropy to another state with lower enthalpy and higher entropy . [7].

\section{CONCLUSION}

By means of isothermal heat treatments of Ghars PPO,the thermal inactivation kinetics was determined. The kinetic data show that triphenolic activity of tedala PPO is more heat stable than o-diphenolic activity of others sources with low and high values of $\mathrm{Zt}$ and Ea respectively..A biphasic model was used to well describe the thermal inactivation behavior of two distinct thermostability fractions. The obtained data show thermal denaturation is mainly under entropic control and it suggests that high temperature should be preferred with long heating time to achieve efficient deactivation of PPO.Further insight is needed in thermal induced quality changes for a total optimization of the heat treatment of dates..

\section{REFERENCES}

[1] M.A Al-Farsi, C.Y.Lee. Nutritional and functional properties of dates: a review. Crit Rev Food Sci Nutr.;48:877e 87.2008.

[2] D.Redondo,M.E. Venturini,R.Oria,,E. Arias, Inhibitory effect of microwaved thinned nectarine extracts on polyphenol oxidase activity. Food Chemistry.,197,603-610. 2016. https://doi.org/10.1016/j.foodchem.2015.11.009

[3] X.FCheng,M.Zhang,B.Adhikari,.The inactivation kinetics of polyphenol oxidase in mushroom (Agaricus bisporus) during thermal and thermosonic treatments, Ultrasonics Sonochemistry.20,674-679.2013.

[4] N.S.Terefe,A.Delon,C.Versteeg.Thermal and high pressure inactivation kinetics of blueberry peroxidase. Food Chem.2017 https://doi.org/10.1016/j.foodchem.2017.04.081

[5] X .Cao,C.Cai,Y.Wang ,X.Zheng.The inactivation kinetics of polyphenol oxidase and peroxidase in bayberry juice during thermal and ultrasound treatments. Innovative Food Science and Emerging Technologies.V 45. Pages 169-178 .2018

[6] N.S.Terefe,A.Delon,R.Buckow,C.Versteeg.Blueberry polyphenol oxidase: Characterization and the kinetics of thermal and high 
pressure activation and inactivation.Food Chemistry,V188,P193200.2015

[7] H.Gouzi,C.Depagne, T.Coradin.Kinetics and thermodynamics of the thermal inactivation of polyphenol oxidase in an aqueous extract from Agaricus bisporus. J of Agric Food Chemy, 60, 500506.2012

[8] Y. Fan, \& W.H.Flurkey.. Purification and characterization of tyrosinase from gill tissue of Portabella mushrooms. Phytochemistry. 65: 671-678.2004.

[9] A.G.Ling,D.B. Lund .Determining kinetic parameters for thermal inactivation of heat resistant and heat- labile isozymes from thermal destruction curves. J Food Sci 43:1307-1310.1978

[10] G. Râpeanu,A.Van Loey,C Smout,\& M. Hendrickx, .Biochemical characterization and process stability of polyphenol oxidase extracted from Victoria grape (Vitis vinifera ssp. Sativa). Food Chemistry. 94, 253-261. 2006. https://doi.org/10.1016/j.foodchem.2004.10.058

[11] N.S.Terefea,Y. Hong Yang,K.Knoerzera,R.Buckowa ,C.Versteeg.High pressure and thermal inactivation kinetics of polyphenol oxidase and peroxidase in strawberry puree. Innovative Food Science \& Emerging Technologies. 11(1):52-60 2010.

[12] C.C.Lago,C.P.Z.Noreña. Kinetic and Thermodynamic of Thermal Inactivation of the Peroxidase, Polyphenoloxidase and Inulinase Activities during Blanching of Yacon (Smallanthus sonchifolius) Juice. Food and Bioprocess Technology, Volume 7,pp 35603568. 2014 https://doi.org/10.1007/s11947-014-1366-y

[13] S .Cheema,M.Sommerhalter.Characterization of polyphenol oxidase activity in Ataulfo mang. Food Chemistry. V 171, PP 382387.2015

[14] E.H.Alici, G.GArabaci.Purification of polyphenol oxidase from borage (Trachystemon orientalis L.) by using three-phase partitioning and investigation of kinetic properties. Int Biol Macromol. 1051-1056.2016

[15] V.B.Kumar Anil,T.C.Mohane Kishor,K. Murugan. .Purification and kinetic characterization of polyphenol oxidase from Barbados cherry (Malpighia gelabra L.).Food Chemistry. 110:328-333.2008

[16] M.Erat,Y.Nuri,S.A.Gülşah,A.Demirkol.Partial characte rization of polyphenol oxidase from a hybridized wheat (Triticum aestivum L.) European Food Research and Technology.23,6,899905.2010

[17] L. Fante \& C.P. Zapata Noreña.Enzyme inactivation kinetics and colour changes in Garlic ( Allium sativum L.) blanched under different conditions.Journal of Food Engineering.108(3), 436443.2012

[18] S .O.O.Eze,F.C.Chilaka ,B.C.Nwanguma .Studies on Thermodynamics and Kinetics of Thermo-Inactivation of Some Quality-Related Enzymes in White Yam (Dioscorea rotundata). J Thermodyn Catal. V 1,Issue 1,1000104.2010 https://doi 10.4172/2157-7544.1000104.

[19] K.Bravo,E.Osorio .(2016).Characterization of poly phenol oxidase from Cape gooseberry (Physalis peruviana L.) fruit. Food Chemistry.V197, Part A, , PP 185-190.2016

[20] S.Singh,N.Wadhwa.Biochemical characterization and thermal inactivation of polyphenol oxidase from elephant foot yam (Amorphophallus paeoniifolius). J Food Sci Technol.20852093.2017

[21] A. Sulaiman,M.Farid,F.V. Silva.Strawberry puree processed by thermal, high pressure, or power ultrasound: Process energy requirements and quality modeling during storage. Food Sci Technol Int. 23(4):293-309.2017.

[22] S.N.Gnangui,E.A.Dué.J-P.E,N'guessan Kouadio, ,L.P.Kouamé.Effect of heat treatment on edible yam polyphenol oxidase activity: kinetic and thermody-namic analysis. Journal of animal \& plant sciences. 2, 3,128-137.2009
[23] B.Chutintrasri,A.Noomhorm.Thermal inactivation of polyphenoloxidase in pineapple pure. LWT - Food Science and Technology. V, Iss 5, Pp 492-495.2006

[24] M.E.Bruins,A.E.M.Janssen,R.M.Boom.Thermozymes and their applications. Applied Biochemistry and Biotechnology,. 90, 155181.2001

[25] K.N.Waliszewski,O.Márquez,V.T.Pardio.Quantification and characterisation of polyphenol oxidase from vanilla bean. Food Chemistry,117, 196-203.2009 